\title{
ANN (Artificial Neural Network) Controlled Virtual Laboratory Design for NdFeB Magnet Production
}

\author{
Mustafa KARHAN*, Musa Faruk ÇAKIR
}

\begin{abstract}
Magnets have an important place in electrical and electronic systems and applications nowadays. The developments in the field of magnets have also greatly expanded their usage areas. NdFeB magnets play active and important role in this development. In this study, design of virtual laboratory to be used for the production of nanocomposite $\mathrm{NdFeB}$ magnets has been realized. Maximum energy product $\left(B H_{\max }\right)$ is an important value for permanent magnets. The high $B H_{\max }$ value in small volume for the magnets is a desired criterion. In the study, mathematical functions were created from the data related to $B_{\mathrm{r}}$ (permanent magnetism), $H_{\mathrm{c}}\left(\right.$ magnetic coercivity), $B H_{\text {max }}$, $T_{\mathrm{c}}$ (Curie temperature) and density obtained in the researches on different NdFeB alloys in the laboratory. Additionally, $B_{\mathrm{r}}$ functions were obtained by adding different additives ( $\mathrm{Co}, \mathrm{Ti}, \mathrm{Zr}, \mathrm{Hf}, \mathrm{V}, \mathrm{Ta}, \mathrm{Nb}, \mathrm{Cr}, \mathrm{W}, \mathrm{Mo}, \mathrm{Mn}, \mathrm{Ni}, \mathrm{Sb}, \mathrm{Sn}, \mathrm{Ge}, \mathrm{Al}, \mathrm{Bi}$ ) to the NdFeB magnets. A virtual laboratory is prepared with the created functions. The obtained results from the operation of the virtual laboratory system and the results obtained from Matlab Simulink and ANN (Artificial Neural Network) systems are compared. The designed and performed virtual laboratory system can be used both for industrial purposes and for educational purposes.
\end{abstract}

Keywords: ANN (Artificial Neural Network); $\mathrm{BH}_{\max }$; nanocomposite; $\mathrm{NdFeB;}$ permanent magnet; virtual laboratory

\section{INTRODUCTION}

Permanent magnets have the ability to consistently release magnetic flux to the air gap of a magnetic circuit. The flux density may be regular, irregular, stable or variable in the time. The most important property for a permanent magnet is the maximum energy product $\left(B H_{\max }\right)$. At the beginning of the century, $B H_{\max }$ values of natural magnets were $10 \mathrm{~kJ} / \mathrm{m}^{3}$, while $\mathrm{NdFeB}$ magnets with a value of $400 \mathrm{~kJ} / \mathrm{m}^{3} B H_{\max }$ are made today. Recently, the energy products of nanocomposite $\mathrm{NdFeB}$ hard magnets under laboratory conditions have increased to 1090 $\mathrm{kJ} / \mathrm{m}^{3}$ [1-4]. A remarkable effort has been made to enhance the magnetic and physical properties of NdFeB magnets. Ferromagnetic elements such as iron and cobalt are widely used. Sm-Co and Nd-Fe-B rare earth magnets have a technologically important place because they give a high $B H_{\max }$ value $[1,5]$. Sintered $\mathrm{NdFeB}$ magnets can be added with small amounts of resistant elements (Ti, Zr, Hf, V, Ta, $\mathrm{Nb}, \mathrm{Cr}, \mathrm{W}, \mathrm{Mo}, \mathrm{Mn}, \mathrm{Ni}, \mathrm{Sb}, \mathrm{Sn}, \mathrm{Ge}, \mathrm{Al}, \mathrm{Bi}$ ) to increase their coercivity [6-8]. In addition, the enhanced magnetic and physical properties make these magnets' thermal stability very good [9]. Ferromagnetic metals such as Co and $\mathrm{Ni}$ from the transition elements increase the magnetization and $T_{\mathrm{C}}$, Curie temperature. Elements such as $\mathrm{Mo}, \mathrm{Nb}, \mathrm{Ti}, \mathrm{V}, \mathrm{W}$ which have higher melting temperature than non-magnetic metals and elements such as $\mathrm{Sn}, \mathrm{Ga}, \mathrm{Al}$, $\mathrm{Cu}$ and $\mathrm{Sn}$ with low melting temperature inhibit the growth of grains with the phases that occur at the grain boundaries. They decrease the magnetic interaction between the grains and increase the strength. At the same time, permanent magnetization can be reduced by these non-magnetic phases [10-15]. As a result of many researches, the coercivity values of $\mathrm{Nd}-\mathrm{Fe}-\mathrm{B}$ permanent magnets have been increased by additive elements with high melting temperatures such as $\mathrm{Nb}, \mathrm{Mo}, \mathrm{W}, \mathrm{Ti}[16,17]$. In order to obtain optimum magnetic and physical properties of the magnets, it is necessary to sinter and cool immediately between $650{ }^{\circ} \mathrm{C}$ and $1160{ }^{\circ} \mathrm{C}$ [18]. Sintering is a high temperature process by which material powders combine to one another by diffusion through the effect of temperature and gradually reduce the pore volume between the powders [19]. In multicomponent systems, sintering temperature is set to the lower values of metal with low melting temperature. As the sintering temperature increases, sintering time decreases [20].

Composite materials are composed of two or more of the same or different types of materials combined at a macro level to collect the best properties of the materials in a new and single material. [21]. The nanocomposites are a new type of composite material containing mineral and an amount of nanosized mineral smaller than $10 \%$.

Due to the wide surface area of the nano-sized particles used, mechanical, thermal and magnetic properties show improvements in positive direction. Due to these properties of composite materials, they play active and important role in the production of $\mathrm{NdFeB}$ magnets. $\mathrm{NdFeB}$ magnets have many properties when they are produced as composites. The high magnetism properties in small volume are at the top of these properties. Significant studies on $\mathrm{NdFeB}$ magnets still continue. It is tried to get higher values of magnetism properties by adding various additives.

The obtained data in the production of these magnets have been used for the system we have simulated. In different alloy magnets, the mathematical functions of the magnetic properties which are important for the magnets have been obtained. These functions are $B H_{\max }, H_{\mathrm{c}}$ and $B_{\mathrm{r}}$ functions. The virtual laboratory system was designed and performed using the obtained function, MATLAB Simulink and ANN (Artificial Neural Network). There are studies using ANN on MATLAB/Simulink platform in many fields of engineering [22-26]. In this study, ANN controlled virtual laboratory on MATLAB/Simulink platform is presented at the intersection of electrical electronics engineering, material engineering, and software engineering.

The data we used to obtain mathematical functions was taken from the work of United States patent number 5-183516. $[27,28]$. 


\section{MATHEMATICAL FUNCTIONS OF NANOCOMPOSITE NdFeB ALLOYS \\ 2.1 Data of Mathematical Functions}

Mathematical functions are needed to be used when preparing a virtual laboratory. $B H_{\max }, H_{\mathrm{c}}$ and $B_{\mathrm{r}}$ functions must be obtained using the following data for alloy $15 \mathrm{Nd}$ $(85-\mathrm{x}) \mathrm{Fe}-\mathrm{xB}$. These functions form the basis of the virtual laboratory.

The effect of $\mathrm{B}$ (Boron) element on the magnetic properties of NdFeB magnets is shown in Tab. 1.

Table 1 The Data of 15Nd-(85-x)Fe-xB alloy [27]

\begin{tabular}{|c|c|c|c|}
\hline \multicolumn{4}{|c|}{ Alloy Name: $15 \mathrm{Nd}-(85-\mathrm{x}) \mathrm{Fe}-\mathrm{xB}$} \\
\hline$\% \mathrm{~B}$ & $B_{\mathrm{r}} / \mathrm{kG}$ & $H_{\mathrm{c}} / \mathrm{kOe}$ & $B H_{\max } / \mathrm{MGOe}$ \\
\hline 0 & 0,0 & 0,00 & 0 \\
\hline 2 & 7,5 & 1,3 & 4,1 \\
\hline 3 & 10,4 & 1,8 & 7,0 \\
\hline 4 & 10,8 & 2,8 & 13,4 \\
\hline 6 & 13,0 & 8,0 & 36,5 \\
\hline 7 & 12,9 & 8,2 & 36,0 \\
\hline 8 & 12,1 & 7,3 & 32,1 \\
\hline 10 & 11,9 & 8,0 & 31,9 \\
\hline 12 & 10,5 & 8,2 & 25,2 \\
\hline 17 & 8,7 & 7,6 & 17,6 \\
\hline 23 & 6,8 & 11,3 & 10,9 \\
\hline 30 & 4,2 & 10,7 & 4,0 \\
\hline 32 & 3,0 & 10,2 & 1,8 \\
\hline
\end{tabular}

The effect of $\mathrm{Nd}$ (neodymium) element on the magnetic properties of $\mathrm{NdFeB}$ magnets is shown in Tab. 2 .

Table 2 The Data of $x$ Nd-(92-x)Fe-8B alloy [27]

\begin{tabular}{|c|c|c|c|}
\hline \multicolumn{4}{|c|}{ Alloy Name: $\mathrm{xNd}-(92-\mathrm{x}) \mathrm{Fe}-8 \mathrm{~B}$} \\
\hline$\% \mathrm{Nd}$ & $B_{\mathrm{r}} / \mathrm{kG}$ & $H_{\mathrm{c}} / \mathrm{kOe}$ & $B H_{\max } / \mathrm{kGOe}$ \\
\hline 6 & 0 & 0 & 0 \\
\hline 13 & 13,1 & 4,8 & 29,3 \\
\hline 14 & 12,8 & 7,8 & 36,5 \\
\hline 17 & 11,6 & 9,2 & 31,1 \\
\hline 19 & 10,9 & 11,4 & 28,0 \\
\hline 25 & 5,8 & 12,6 & 8,8 \\
\hline 35 & 1,9 & 14,6 & $\leq 1$ \\
\hline
\end{tabular}

Table 3 The Data of 15Nd-(77-x)Fe-8B-zM alloy [27] Alloy Name: $15 \mathrm{Nd}-(77-\mathrm{x}) \mathrm{Fe}-8 \mathrm{~B}-\mathrm{xM}$

\begin{tabular}{|c|c|c|c|c|c|c|c|c|}
\hline \multicolumn{9}{|c|}{ Alloy Name: $15 \mathrm{Nd}-(77-\mathrm{x}) \mathrm{Fe}-8 \mathrm{~B}-\mathrm{xM}$} \\
\hline \multicolumn{9}{|c|}{$B_{\mathrm{r}}$ values when added additives, $M=$ Added material } \\
\hline$\Sigma$ & $\underset{\sim}{0}$ & $\underline{y}$ & $\underline{\square}$ & પ્y & $\underline{\Xi}$ & $\underset{\nu}{0}$ & $\underset{\nearrow}{0}$ & $\underset{\mathscr{U}}{0}$ \\
\hline $0^{\circ}$ & $\dot{F}$ & $\dot{N}$ & 出 & $>$ & $\stackrel{\pi}{\oplus}$ & $\hat{z}$ & Uे & 3 \\
\hline 0 & 12,0 & 12,0 & 12,0 & 12,0 & 12,0 & 12,0 & 12,0 & 12,0 \\
\hline 0,5 & 12,3 & 11,9 & 11,9 & & 11,6 & & 11,6 & 11,6 \\
\hline 1 & 12,0 & 11,7 & 11,7 & 11,5 & 11,6 & 11,9 & 11,4 & 11,4 \\
\hline 1,5 & 11,8 & 11,4 & 11,4 & & & & & \\
\hline 2 & 11,2 & 10,7 & 10,7 & 11,0 & 11,4 & 11,7 & 10,9 & 11,0 \\
\hline 3 & 8,7 & 9,2 & 9,2 & 10,3 & & & & \\
\hline 4 & 6,0 & 7,5 & 7,5 & 9,8 & 10,5 & 11,0 & 9,5 & 9,8 \\
\hline 5 & 2,4 & 5,3 & 5,3 & & & & & \\
\hline 6 & & 2,2 & 2,2 & 8,5 & 9,5 & 10,2 & 7,6 & 8,0 \\
\hline 7 & & & & & & & & \\
\hline 8 & & & & 7,0 & 8,4 & 9,4 & 5,2 & 5,9 \\
\hline 9 & & & & 5,7 & 7,5 & 9,0 & & \\
\hline 10 & & & & 3,5 & 6,0 & 8,2 & 2,3 & 3,5 \\
\hline 11 & & & & & 3,7 & & & \\
\hline 12 & & & & & & 5,4 & & \\
\hline
\end{tabular}

When additives are added to an alloy, the resulting residual magnetism in the alloy $\left(B_{\mathrm{r}}\right)$ the data used to obtain the required functions in order to observe the changes are given in Tab. 3 and Tab. 4.
Table 4 The Data of 15Nd-(77-x)Fe8B-zM alloy [27] Alloy Name: $15 \mathrm{Nd}-(77-\mathrm{x}) \mathrm{Fe}-8 \mathrm{~B}-\mathrm{xM}$ $B_{\mathrm{r}}$ values when added additives $M=$ Added material

\begin{tabular}{|c|c|c|c|c|c|c|c|}
\multicolumn{7}{|c}{$M=$ Added material } \\
\hline$\% M$ & $\mathrm{Mn}$ & $\mathrm{Ni}$ & $\mathrm{Sb}$ & $\mathrm{Sn}$ & $\mathrm{Ge}$ & $\mathrm{Al}$ & $\mathrm{Bi}$ \\
\hline 0,0 & 12,0 & 12,0 & 12,0 & 12,0 & 12,0 & 12,0 & 12,0 \\
\hline 0,5 & 11,3 & 11,8 & & & 11,4 & 12,1 & \\
\hline 1,0 & 10,7 & 11,9 & 9,2 & 10,0 & 11,0 & 11,4 & 11,7 \\
\hline 1,5 & & & & & & & \\
\hline 2,0 & 9,9 & 11,6 & 6,1 & 7,8 & 10,3 & 10,9 & 11,4 \\
\hline 3,0 & & & & 5,5 & & & \\
\hline 4,0 & 9,1 & 11,1 & 2,9 & 3,5 & 8,4 & 9,6 & 10,4 \\
\hline 5,0 & & & & & & & 10,0 \\
\hline 6,0 & 8,7 & 10,2 & & & 6,5 & 8,4 & \\
\hline 7,0 & & & & & & & \\
\hline 8,0 & 8,2 & 9,2 & & & 3,5 & 6,4 & \\
\hline 9,0 & & & & & & & \\
\hline 10,0 & 7,3 & 8,0 & & & & 3,4 & \\
\hline
\end{tabular}

\section{$2.2 B_{r}$ Functions}

$B_{\mathrm{r}}$ functions are directly effective as a multiplier in determining $B H_{\max }$ for alloys. It is a common value for different alloy structures. It is also used for magnet characterization for different magnet alloys. These are functions of residual magnetism when $\% M$ additives $(M=$ $\mathrm{Ti}, \mathrm{Zr}, \mathrm{Hf}, \mathrm{V}, \mathrm{Ta}, \mathrm{Nb}, \mathrm{Cr}, \mathrm{W}, \mathrm{Mo}, \mathrm{Mn}, \mathrm{Ni}, \mathrm{Sb}, \mathrm{Sn}, \mathrm{Ge}, \mathrm{Al}$, $\mathrm{Bi}$ ) are added to the $15 \mathrm{Nd}-\mathrm{Fe}-8 \mathrm{~B}-\mathrm{xM}$ alloy from the obtained alloys and they are pressed in $10 \mathrm{kOe}$ magnetic field. The obtained $B_{\mathrm{r}}$ functions for the different additives are given in Eqs. (1) to (15).

Alloy Formula: 15 Nd-(77-x)Fe-8B-xM

$(M=\mathrm{Ti}, \mathrm{Zr}, \mathrm{Hf}, \mathrm{V}, \mathrm{Ta}, \mathrm{Nb}, \mathrm{Cr}, \mathrm{W}, \mathrm{Mo}, \mathrm{Mn}, \mathrm{Ni}, \mathrm{Sb}, \mathrm{Sn}, \mathrm{Ge}$, $\mathrm{Al}, \mathrm{Bi})$.

$$
\begin{aligned}
& F B_{\mathrm{r}}(\mathrm{Ti})=-0,02969 \cdot x^{6}+0,4061 \cdot x^{5}-2,03 \cdot x^{4}+ \\
& +4,555 \cdot x^{3}-5,048 \cdot x^{2}+2,181 \cdot x+12 \\
& F B_{\mathrm{r}}(\mathrm{Zr})=0,002656 \cdot x^{6}-0,04875 \cdot x^{5}+0,3254 \cdot x^{4}- \\
& -0,9443 \cdot x^{3}+0,8405 \cdot x^{2}-0,4438 \cdot x+12 \\
& F B_{\mathrm{r}}(\mathrm{Hf})=0,002656 \cdot x^{6}-0,04875 \cdot x^{5}+0,3254 \cdot x^{4}- \\
& -0,9443 \cdot x^{3}+0,8405 \cdot x^{2}-0,4438 \cdot x+12 \\
& F B_{\mathrm{r}}(\mathrm{V})=2,769 \times 10^{-5} \cdot x^{6}+0,0005505 \cdot x^{5}- \\
& -0,004751 \cdot x^{4}+0,02434 \cdot x^{3}-0,8509 \cdot x^{2}- \\
& -0,4179 \cdot x+12 \\
& F B_{r}(\mathrm{Ta})=9,06 \times 10^{-5} \cdot x^{6}-0,003284 \cdot x^{5}+ \\
& 0,04315 \cdot x^{4}-0,02561 \cdot x^{3}+0,6518 \cdot x^{2}- \\
& -0,8792 \cdot x+12 \\
& F B_{\mathrm{r}}(\mathrm{Nb})=1,69410 \times 10^{-5} \cdot x^{6}-0,0006699 \cdot x^{5}+ \\
& 0,04315 \cdot x^{4}-0,04354 \cdot x^{3}+0,03859 \cdot x^{2}- \\
& -0,1106 \cdot x+12 \\
& F B_{\mathrm{r}}(\mathrm{Cr})=0,0001103 \cdot x^{6}-0,003334 \cdot x^{5}+0,03832 \cdot x^{4}- \\
& -0,209 \cdot x^{3}+0,4847 \cdot x^{2}-0,9313 \cdot x+11,99 \\
& F B_{\mathrm{r}}(\mathrm{W})=7,928 \times 10^{-5} \cdot x^{6}-0,002619 \cdot x^{5}+ \\
& +0,03346 \cdot x^{4}-0,2043 \cdot x^{3}+0,5359 \cdot x^{2}- \\
& -0,9768 \cdot x+11,99
\end{aligned}
$$




$$
\begin{aligned}
& F B_{\mathrm{r}}(\mathrm{Mo})=-5,397 \times 10^{-5} \cdot x^{6}+0,001243 \cdot x^{5}- \\
& -0,00874 \cdot x^{4}+0,01178 \cdot x^{3}+0,01955 \cdot x^{2}- \\
& -0,4964 \cdot x+12,01 \\
& F B_{\mathrm{r}}(\mathrm{Mn})=9,515 \times 10^{-6} \cdot x^{6}+0,0002207 \cdot x^{5}- \\
& -0,0008097 \cdot x^{4}-0,02473 \cdot x^{3}+0,3136 \cdot x^{2}- \\
& -1,579 \cdot x+12 \\
& F B_{\mathrm{r}}(\mathrm{Ni})=-1,097 \times 10^{-5} \cdot x^{6}+0,0001658 \cdot x^{5}+ \\
& +0,0004199 \cdot x^{4}-0,01631 \cdot x^{3}+0,0453 \cdot x^{2}- \\
& -0,2002 \cdot x+11,98 \\
& F B_{\mathrm{r}}(\mathrm{Sb})=0,1 \cdot x^{2}-2,74 \cdot x+12,01 \\
& F B_{\mathrm{r}}(\mathrm{Ge})=0,002315 \cdot x^{5}+0,0429 \cdot x^{4}-0,279 \cdot x^{3}+ \\
& +0,7251 \cdot x^{2}-1,489 \cdot x+12 \\
& F B_{\mathrm{r}}(\mathrm{Al})=-0,0001244 \cdot x^{6}+0,004023 \cdot x^{5}- \\
& -0,04979 \cdot x^{4}+0,2833 \cdot x^{3}-0,7224 \cdot x^{2}+ \\
& +0,03448 \cdot x+12,05 \\
& F B_{\mathrm{r}}(\mathrm{Bi})=0,008333 \cdot x^{4}+0,075 \cdot x^{3}+0,1667 \cdot x^{2}- \\
& -0,4 \cdot x+12
\end{aligned}
$$

\section{$2.3 B H_{\max }$ and $H_{\mathrm{c}}$ Functions}

From the alloys formed to observe the effects of $\mathrm{Nd}$ and $\mathrm{B}$; The effect of $\mathrm{B}$ with $15 \mathrm{Nd}-(85-\mathrm{x}) \mathrm{Fe}-\mathrm{xB}$ and the effect of Nd with $\mathrm{xNd}-(92-\mathrm{x}) \mathrm{Fe}-8 \mathrm{~B}$ alloy were investigated and $\mathrm{Br}$ and $\mathrm{Hc}$ functions were established for $\% \mathrm{~B}$ change and $\% \mathrm{Nd}$ change. The obtained $B_{\mathrm{r}}, H_{\mathrm{c}}$ and $B H_{\max }$ functions for $15 \mathrm{Nd}-(85-\mathrm{x}) \mathrm{Fe}-\mathrm{xB}$ are given in Eqs. (16) to (18). The obtained $B_{\mathrm{r}}, H_{\mathrm{c}}$ and $B H_{\max }$ functions for xNd-(92-x)Fe-8B are given in Eqs. (19) to (21).

Alloy Formula: $15 \mathrm{Nd}-(85-\mathrm{x}) \mathrm{Fe}-\mathrm{xB}$

$$
\begin{aligned}
& F B_{\mathrm{r}}(\mathrm{B})=9,754 \times 10^{-6} \cdot x^{5}-0,0009972 \cdot x^{4}+ \\
& +0,03813 \cdot x^{3}-0,6705 \cdot x^{2}+4,959 \cdot x+0,05367 \\
& F H_{\mathrm{c}}(\mathrm{B})=-8,322 \times 10^{-5} \cdot x^{4}+0,006099 \cdot x^{3}- \\
& -0,1613 \cdot x^{2}+2,004 \cdot x-1,316 \\
& F B H_{\max }(\mathrm{B})=-0,0001754 \cdot x^{4}+0,02022 \cdot x^{3}- \\
& -0,7541 \cdot x^{2}+9,474 \cdot x-6,858
\end{aligned}
$$

Alloy Formula: xNd-(92-x)Fe-8B

$$
\begin{aligned}
& F B_{\mathrm{r}}(\mathrm{Nd})=-0,0001578 \cdot x^{4}+0,01715 \cdot x^{3}- \\
& -0,6637 \cdot x^{2}+10,21 \cdot x-40,84 \\
& F H_{\mathrm{c}}(\mathrm{Nd})=-8,242 \times 10^{-5} \cdot x^{3}-0,01436 \cdot x^{2}+ \\
& +1,217 \cdot x-6,966 \\
& F B H_{\max }(\mathrm{Nd})=0,00026 \cdot x^{4}-0,006882 \cdot x^{3}- \\
& -0,4002 \cdot x^{2}+13,11 \cdot x-63,16
\end{aligned}
$$

Using the above functions, the following virtual laboratory was prepared. Screen shot of the developed virtual laboratory software is given in Fig. 1.

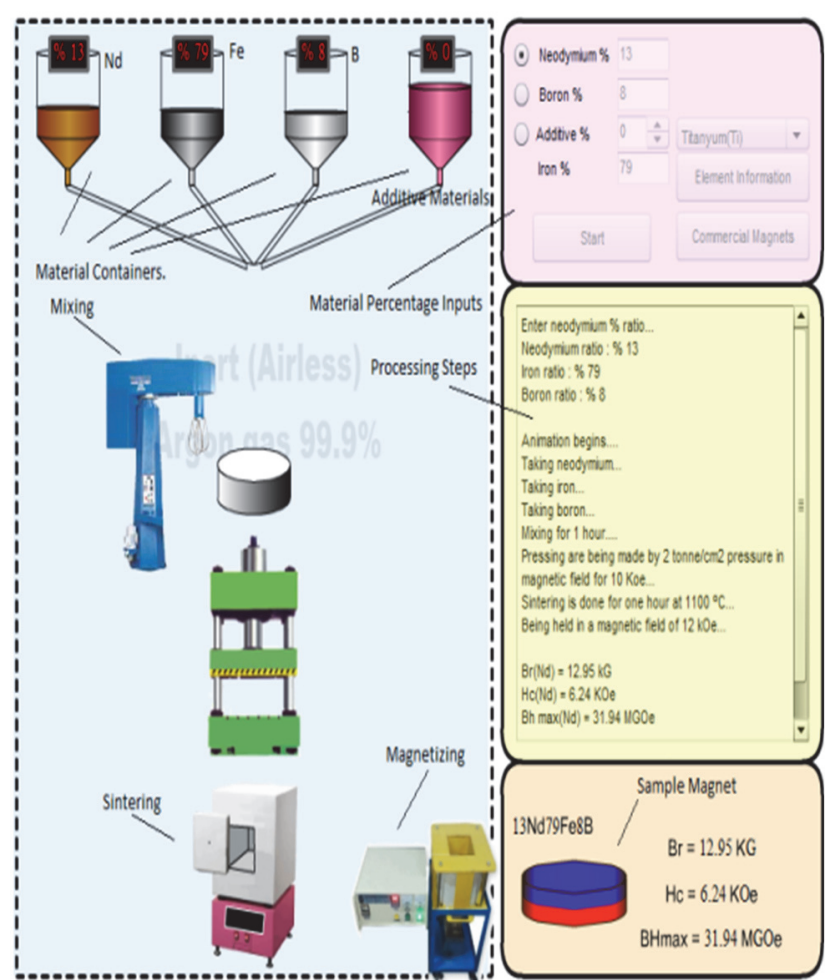

Figure 1 Screen shot of the developed virtual laboratory software [1]

When we want to produce magnet based on $\mathrm{Nd}$ element, when we input $\mathrm{Nd}$ value as \% in our virtual laboratory, the system works and the alloy formula and $\mathrm{BH}_{\max }$ values of the sample are obtained. We can obtain $\mathrm{NdFeB}$ alloys by doing the same steps for element $\mathrm{B}$. When we select the additive and enter the $\%$ ratio in our virtual laboratory we get the residual magnetization value of the alloy $15 \mathrm{Nd}-\mathrm{Fe}-8 \mathrm{~B}-\mathrm{xM}$ to investigate the effect of additives on the residual magnetism $\left(B_{\mathrm{r}}\right)$ of the $\mathrm{NdFeB}$ magnet $(M=$ Additives).

Today's commercial magnets are also included in the virtual lab. $B_{\mathrm{r}}, B H_{\max }$ and commercial magnets can be selected according to operating temperatures. We can also investigate the chemical and physical properties of all the elements.

\section{CONTROLLING OF VIRTUAL LABORATORY WITH ARTIFICIAL NEURAL NETWORK}

The block diagram of the controlling of virtual laboratory with artificial neural network (ANN) is given below (Fig. 2).

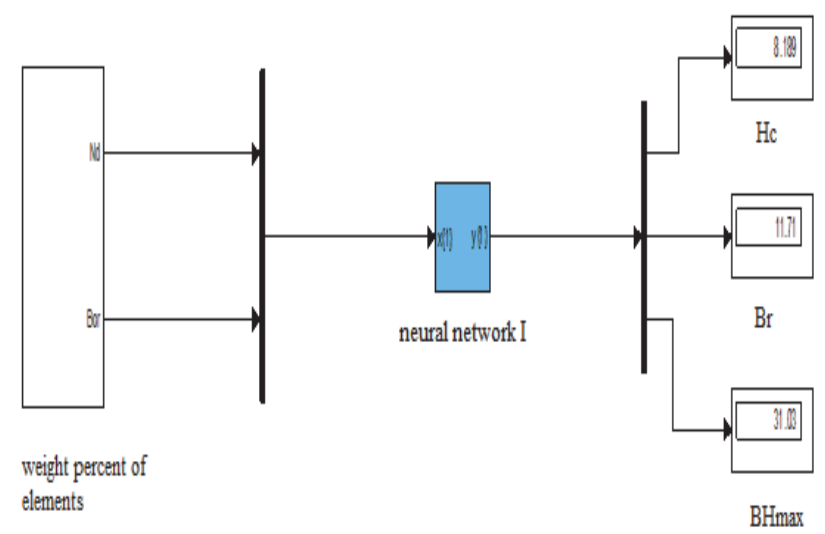

Figure 2 The block diagram of the controlling of virtual laboratory 
5-layer ANN block and internal structure are shown below (Fig. 3) [29, 30].

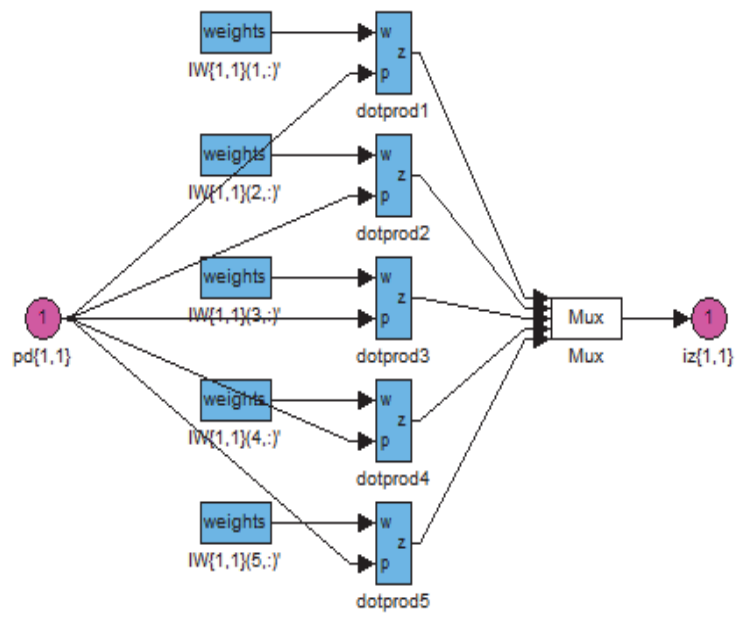

Figure 3 5-layer ANN block. [24, 25]

The graphs of $B_{\mathrm{r}}, H_{\mathrm{c}}$ and $B H_{\max }$ for $\mathrm{Nd}$ and $\mathrm{B}$ changes are shown below (Fig. 4 and Fig. 5) when the above ANN block diagram is run for all input values.
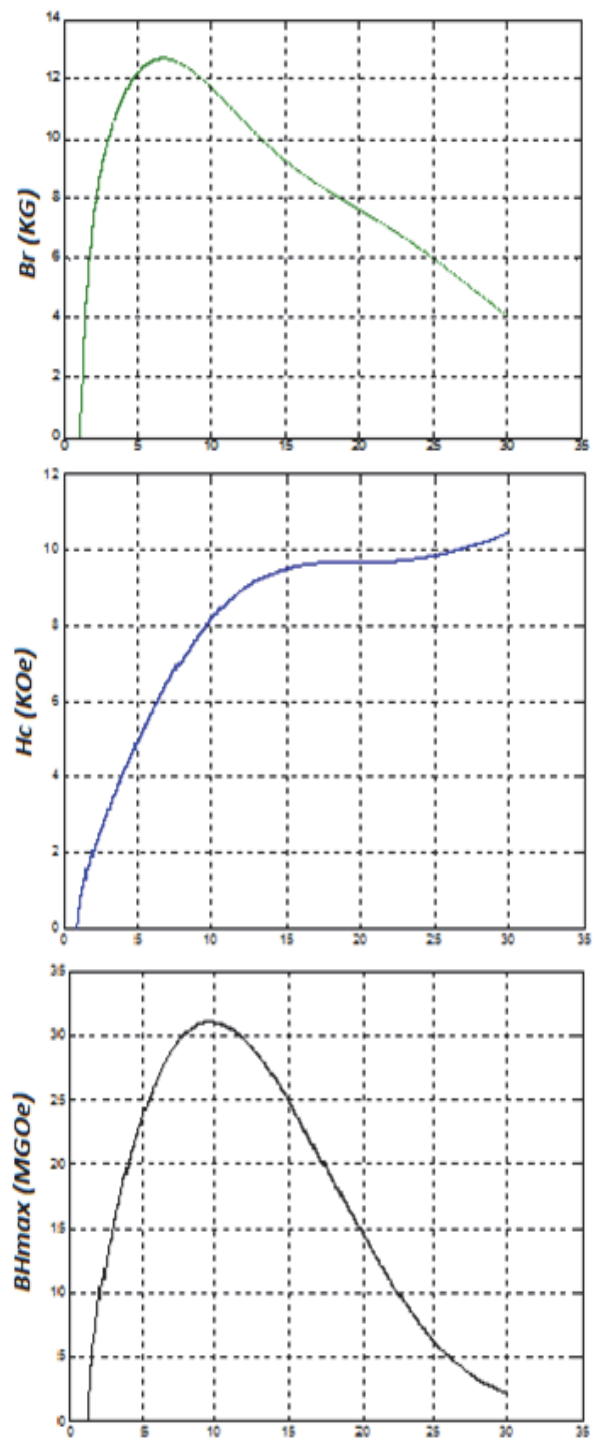

\% B Change

Figure $4 B_{r}, H_{c}$ and $B H_{\max }$ graphs versus $\% B$ change in the results of ANN
When the above chart is analysed, the highest value of the $B H_{\max }$ of the magnet is about $10 \%$ of the $\mathrm{B}$ (Boron) value.The graph of magnetic property which is important for the magnet $\left(B H_{\max }, B_{\mathrm{r}}\right.$ and $\left.H_{\mathrm{c}}\right)$ should be examined in detail. In some magnets, the coercivity $\left(H_{\mathrm{c}}\right)$ may be more important than $B H_{\max }$. In these cases, the graphical values of the coercivity $\left(H_{\mathrm{c}}\right)$ should be chosen in the most ideal way.

When the below chart is analysed, the highest value of the $B H_{\max }$ of the magnet is about $15 \%$ of the $\mathrm{Nd}$ (Neodymium) value. If the $B_{\mathrm{r}}$ value is more important than $B H_{\max }$, the $\mathrm{Nd}$ value should be around $10-15 \%$. Which properties of the magnets produced are more important should be determined and the $\% \mathrm{Nd}$ value should be adjusted. The obtained values using by ANN provided a more robust and reliable virtual laboratory.
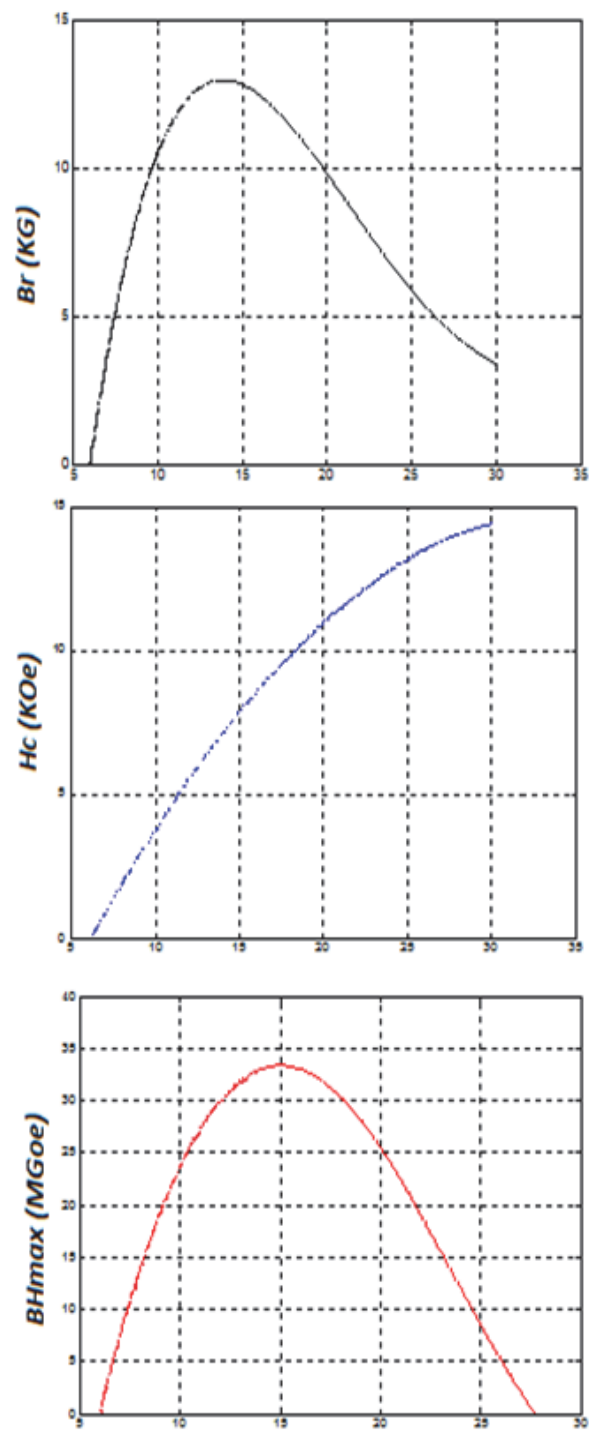

$\%$ Nd Change

Figure $5 B_{r}, H_{c}$ and $B H_{\max }$ graphs versus $\% \mathrm{Nd}$ change in the results of ANN

\section{CONCLUSION AND SUGGESTIONS}

In order to test the prepared virtual laboratory, studies with the same values as the environment values (mixing time, pressure, applied magnetic field, sintering temperature and sintering time) in the preparation of the 
data we use were used. The following results were obtained when we compared the results. Comparison of all results is given in Tab. 5 .

The algorithm, which was followed when performing experiments in the real laboratory environment, was also used in preparing the virtual laboratory environment. In this way it is possible to compare actual test results with software results. The values of results of virtual labs are close to the averages of ANN results with real experiments. The results in each section are very close together. Through virtual laboratory, it is possible to make magnet experiments by mixing materials in desired rate. The software can simulate interim values for the currently manufactured magnet alloys. In this way, both the time spent in the production of samples and the material costs are eliminated.

By means of the prepared virtual laboratory, we can obtain the properties of the produced commercial magnets. In this section you can see whether there is a magnet in the desired properties. The properties of the magnet you need are also available from this part. In addition, physical and chemical properties of the used elements can be studied.

Table $\mathbf{5}$ Comparison of virtual laboratory results, artificial neural networks and other study results

\begin{tabular}{|c|c|c|}
\hline \multicolumn{3}{|c|}{ Comparison of Laboratory Results } \\
\hline Virtual Laboratory & ANN & Simulink \\
\hline \multicolumn{3}{|c|}{$\mathrm{Nd}=20, \mathrm{~B}=820 \mathrm{Nd} 72 \mathrm{Fe} 8 \mathrm{~B}$ Alloy } \\
\hline $\begin{array}{c}B_{\mathrm{r}}=10.15 \mathrm{kG} \\
H_{\mathrm{c}}=10.97 \mathrm{kOe} \\
B H_{\max }=25.5 \mathrm{MGOe}\end{array}$ & $\begin{aligned} B_{\mathrm{r}} & =9.843 \mathrm{kG} \\
H_{\mathrm{c}} & =10.9 \mathrm{kOe} \\
B H_{\max } & =25.58 \mathrm{MGOe}\end{aligned}$ & $\begin{aligned} B_{\mathrm{r}} & =9.832 \mathrm{kG} \\
H_{\mathrm{c}} & =10.96 \mathrm{kOe} \\
B H_{\max } & =25.55 \mathrm{MGOe}\end{aligned}$ \\
\hline \multicolumn{3}{|c|}{$\mathrm{Nd}=10, \mathrm{~B}=8 \quad 10 \mathrm{Nd} 82 \mathrm{Fe} 8 \mathrm{~B}$ Alloy } \\
\hline $\begin{aligned} B_{\mathrm{r}} & =10.48 \mathrm{kG} \\
H_{\mathrm{c}} & =3.68 \mathrm{kOe} \\
B H_{\max } & =23.63 \mathrm{MGOe}\end{aligned}$ & $\begin{aligned} B_{\mathrm{r}} & =10.51 \mathrm{kG} \\
H_{\mathrm{c}} & =3.717 \mathrm{kOe} \\
B H_{\max } & =23.61 \mathrm{MGOe}\end{aligned}$ & $\begin{array}{c}B_{\mathrm{r}}=10.46 \mathrm{kG} \\
H_{\mathrm{c}}=3.684 \mathrm{kOe} \\
B H_{\max }=23.67 \mathrm{MGOe}\end{array}$ \\
\hline \multicolumn{3}{|c|}{$\mathrm{Nd}=15, \mathrm{~B}=1015 \mathrm{Nd} 75 \mathrm{Fe} 10 \mathrm{~B}$ Alloy } \\
\hline $\begin{aligned} B_{\mathrm{r}} & =11.72 \mathrm{kG} \\
H_{\mathrm{c}} & =7.86 \mathrm{kOe} \\
B H_{\max } & =30.93 \mathrm{MGOe}\end{aligned}$ & $\begin{aligned} B_{\mathrm{r}} & =11.71 \mathrm{kG} \\
H_{\mathrm{c}} & =8.189 \mathrm{kOe} \\
B H_{\max } & =31.03 \mathrm{MGOe}\end{aligned}$ & $\begin{array}{c}B_{\mathrm{r}}=11.7 \mathrm{kG} \\
H_{\mathrm{c}}=8.118 \mathrm{kOe} \\
B H_{\max }=30.94 \mathrm{MGOe}\end{array}$ \\
\hline \multicolumn{3}{|c|}{$\mathrm{Nd}=17, \mathrm{~B}=817 \mathrm{Nd} 75 \mathrm{Fe} 8 \mathrm{~B}$ Alloy } \\
\hline $\begin{aligned} B_{\mathrm{r}} & =12.16 \mathrm{kG} \\
H_{\mathrm{c}} & =9.16 \mathrm{kOe} \\
B H_{\max } & =31.95 \mathrm{MGOe}\end{aligned}$ & $\begin{aligned} B_{\mathrm{r}} & =11.99 \mathrm{kG} \\
H_{\mathrm{c}} & =9.156 \mathrm{kOe} \\
B H_{\max } & =32.09 \mathrm{MGOe}\end{aligned}$ & $\begin{array}{c}B_{\mathrm{r}}=12 \mathrm{kG} \\
H_{\mathrm{c}}=9.159 \mathrm{kOe} \\
B H_{\max }=31.99 \mathrm{MGOe}\end{array}$ \\
\hline \multicolumn{3}{|c|}{$\mathrm{Nd}=7, \mathrm{~B}=8 \mathrm{7Nd} 85 \mathrm{Fe} 8 \mathrm{~B}$ Alloy } \\
\hline $\begin{aligned} B_{\mathrm{r}} & =3.61 \mathrm{kG} \\
H_{\mathrm{c}} & =0.82 \mathrm{kOe} \\
B H_{\max } & =7.26 \mathrm{MGOe}\end{aligned}$ & $\begin{array}{c}B_{\mathrm{r}}=3.604 \mathrm{kG} \\
H_{\mathrm{c}}=0.7575 \mathrm{kOe} \\
B H_{\max }=7.359 \mathrm{MGOe}\end{array}$ & $\begin{array}{c}B_{\mathrm{r}}=3.612 \mathrm{kG} \\
H_{\mathrm{c}}=0.8205 \mathrm{kOe} \\
B H_{\max }=7.287 \mathrm{MGOe}\end{array}$ \\
\hline \multicolumn{3}{|c|}{$\mathrm{Nd}=27, \mathrm{~B}=827 \mathrm{Nd} 65 \mathrm{Fe} 8 \mathrm{~B}$ Alloy } \\
\hline $\begin{aligned} B_{\mathrm{r}} & =5.75 \mathrm{kG} \\
H_{\mathrm{c}} & =13.8 \mathrm{kOe} \\
B H_{\max } & =1.78 \mathrm{MGOe}\end{aligned}$ & $\begin{aligned} B_{\mathrm{r}} & =4.685 \mathrm{kG} \\
H_{\mathrm{c}} & =13.78 \mathrm{kOe} \\
B H_{\max } & =2.012 \mathrm{MGOe}\end{aligned}$ & $\begin{aligned} B_{\mathrm{r}} & =4.695 \mathrm{kG} \\
H_{\mathrm{c}} & =13.77 \mathrm{kOe} \\
B H_{\max } & =1.812 \mathrm{MGOe}\end{aligned}$ \\
\hline \multicolumn{3}{|c|}{$\mathrm{Nd}=15, \mathrm{~B}=1515 \mathrm{Nd} 70 \mathrm{Fe} 15 \mathrm{~B}$ Alloy } \\
\hline $\begin{aligned} B_{\mathrm{r}} & =9.18 \mathrm{kG} \\
H_{\mathrm{c}} & =8.82 \mathrm{kOe} \\
B H_{\max } & =24.94 \mathrm{MGOe}\end{aligned}$ & $\begin{aligned} B_{\mathrm{r}} & =9.273 \mathrm{kG} \\
H_{\mathrm{c}} & =9.491 \mathrm{kOe} \\
B H_{\max } & =24.94 \mathrm{MGOe}\end{aligned}$ & $\begin{aligned} B_{\mathrm{r}} & =9.294 \mathrm{kG} \\
H_{\mathrm{c}} & =9.487 \mathrm{kOe} \\
B H_{\max } & =24.94 \mathrm{MGOe}\end{aligned}$ \\
\hline \multicolumn{3}{|c|}{$\mathrm{Nd}=15, \mathrm{~B}=2015 \mathrm{Nd} 65 \mathrm{Fe} 20 \mathrm{~B}$ Alloy } \\
\hline $\begin{aligned} B_{\mathrm{r}} & =7.73 \mathrm{kG} \\
H_{\mathrm{c}} & =9.72 \mathrm{kOe} \\
B H_{\max } & =14.67 \mathrm{MGOe}\end{aligned}$ & $\begin{aligned} B_{\mathrm{r}} & =7.635 \mathrm{kG} \\
H_{\mathrm{c}} & =9.673 \mathrm{kOe} \\
B H_{\max } & =14.59 \mathrm{MGOe}\end{aligned}$ & $\begin{aligned} B_{\mathrm{r}} & =7.602 \mathrm{kG} \\
H_{\mathrm{c}} & =9.82 \mathrm{kOe} \\
B H_{\max } & =14.68 \mathrm{MGOe}\end{aligned}$ \\
\hline \multicolumn{3}{|c|}{$\mathrm{Nd}=15, \mathrm{~B}=2515 \mathrm{Nd} 60 \mathrm{Fe} 25 \mathrm{~B}$ Alloy } \\
\hline $\begin{array}{c}B_{\mathrm{r}}=6.47 \mathrm{kG} \\
H_{\mathrm{c}}=10.76 \mathrm{kOe} \\
B H_{\max }=6.1 \mathrm{MGOe}\end{array}$ & $\begin{aligned} B_{\mathrm{r}} & =6.006 \mathrm{kG} \\
H_{\mathrm{c}} & =9.847 \mathrm{kOe} \\
B H_{\max } & =6.235 \mathrm{MGOe}\end{aligned}$ & $\begin{aligned} B_{\mathrm{r}} & =6.074 \mathrm{kG} \\
H_{\mathrm{c}} & =9.848 \mathrm{kOe} \\
B H_{\max } & =6.101 \mathrm{MGOe}\end{aligned}$ \\
\hline \multicolumn{3}{|c|}{$\mathrm{Nd}=25 \mathrm{~B}=8 \quad 25 \mathrm{Nd} 67 \mathrm{Fe} 8 \mathrm{~B}$ Alloy } \\
\hline $\begin{array}{c}B_{\mathrm{r}}=6.7 \mathrm{kG} \\
H_{\mathrm{c}}=13.19 \mathrm{kOe} \\
B H_{\max }=8.49 \mathrm{MGOe}\end{array}$ & $\begin{array}{c}B_{\mathrm{r}}=5.91 \mathrm{kG} \\
H_{\mathrm{c}}=13.17 \mathrm{kOe} \\
B H_{\max }=8.503 \mathrm{MGOe}\end{array}$ & $\begin{aligned} B_{\mathrm{r}} & =5.926 \mathrm{kG} \\
H_{\mathrm{c}} & =13.17 \mathrm{kOe} \\
B H_{\max } & =8.544 \mathrm{MGOe}\end{aligned}$ \\
\hline
\end{tabular}

\section{REFERENCES}

[1] Çakır, M. F.,Tarımer, İ., \& Gürdal, O. (2014). Designing a virtual laboratory for simulating to production of nanocomposite NdFeB magnets. TEM Journal, 3(1), 8-12.

[2] Crangle, J. (1977). The Magnetic Properties of Solids. Edward Arnold, London.

[3] Yalçın, H. \& Gürü, M. (2002). Malzeme Bilgisi. Palme Yayınevi.

[4] Shandong, L., Yaodong, D., Gu, B. X., Zongjun, T., \& Youwei, D. (2002). Effect of amorphous grain boundaries on the magnetic properties of B-rich nanocomposite permanent magnets. Journal of alloys and compounds, 339(1-2), 202206. https://doi.org/10.1016/S0925-8388(01)01992-2

[5] Corner, W. D. (1988). Permanent magnets. Physics in Technology, 19(4), 158.

\section{https://doi.org/10.1088/0305-4624/19/4/305}

[6] Sagawa, M., Fujimura, S., Togawa, N., Yamamoto, H., \& Matsuura, Y. (1984). New material for permanent magnets on a base of Nd and Fe. Journal of Applied Physics, 55(6), 2083-2087. https://doi.org/10.1063/1.333572

[7] Herbst, J. F. (1991). $\mathrm{R}_{2} \mathrm{Fe}_{14} \mathrm{~B}$ materials: Intrinsic properties and technological aspects. Reviews of Modern Physics, 63(4), 819. https://doi.org/10.1103/RevModPhys.63.819

[8] Buschow, K. H. J. (1997). Magnetism and processing of permanent magnet materials. Handbook of magnetic materials, 10, 463-593. https://doi.org/10.1016/S1567-2719(97)10008-7

[9] Sagawa, M., Tenaud, P., Vial, F., \& Hiraga, K. (1990). High coercivity $\mathrm{Nd}-\mathrm{Fe}-\mathrm{B}$ sintered magnet containing vanadium with new microstructure. IEEE transactions on magnetics, 26(5), 1957-1959. https://doi.org/10.1109/20.104581 
[10] Vial, F., Joly, F., Nevalainen, E., Sagawa, M., Hiraga, K., \& Park, K. T. (2002). Improvement of coercivity of sintered $\mathrm{NdFeB}$ permanent magnets by heat treatment. Journal of magnetism and magnetic materials, 242, 1329-1334. https://doi.org/10.1016/S0304-8853(01)00967-2

[11] Croat, J. J., Herbst, J. F., Lee, R. W., \& Pinkerton, F. E. (1984). Pr-Fe and Nd-Fe-based materials: A new class of high-performance permanent magnets. Journal of Applied Physics, 55(6), 2078-2082. https://doi.org/10.1063/1.333571

[12] Yang, S., Song, X., Li, S., Liu, X., Tian, Z., Gu, B., \& Du, Y. (2003). Effect of $\mathrm{Cu}$ and $\mathrm{Ti}$ additions on the microstructures and magnetic properties of Nd8Fe86B6 nanocomposite magnets. Journal of magnetism and magnetic materials, 263(1-2), 134-140. https://doi.org/10.1016/S0304-8853(02)01546-9

[13] Yan, A., Song, X., \& Wang, X. (1997). Effect of minor intergranular additives on microstructure and magnetic properties of $\mathrm{NdFeB}$ based magnets. Journal of magnetism and magnetic materials, 169(1-2), 193-198. https://doi.org/10.1016/S0304-8853(96)00713-5

[14] Rodewald, W. \& Fernengel, W. (1988). Properties of sintered Nd-Fe-TM-B magnets. IEEE Transactions on Magnetics, 24(2), 1638-1640. https://doi.org/10.1109/20.11555

[15] Gholamipour R. R., Beitollahi A., Marghusan V., Ohkubo V., \& Hono, K. Proc. of 19th International Workshop on Rare Earth Permanent Magnets and Their Applications, 215-220.

[16] Ishikawa, T., Hamada, Y., \& Ohmori, K. (1989). Domain wall pinning by fine precipitates. IEEE Transactions on Magnetics, 25(5), 3434-3436. https://doi.org/10.1109/20.42326

[17] Otani, Y., Miyajima, H., \& Chikazumi, S. (1989). Large Barkhausen jumps observed in Nd-Fe-B sintered magnets at very low temperatures. IEEE Transactions on Magnetics, 25(5), 3431-3433. https://doi.org/10.1109/20.42325

[18] Ragg, O. M. \& Harris, I. R. (1997). A study of the effects of the addition of various amounts of $\mathrm{Cu}$ to sintered Nd-Fe-B magnets. Journal of alloys and compounds, 256(1-2), 252257. https://doi.org/10.1016/S0925-8388(96)02962-3

[19] Erdoğan, M. (1998). Malzeme Bilimi ve Mühendislik Malzemeleri. Nobel Yayınevi, Ankara.

[20] Sümer, M. (2004). Mekanik alaşımlama ile üretilen $\mathrm{Fe}-\mathrm{Fe}_{3} \mathrm{C}$ kompozitmalzemede mekanik özelliklerin araştırılması. Yüksek Lisans Tezi, Gazi Üniversitesi Fen Bilimleri Enstitüsü, Ankara.

[21] Şahin, Y. (2000). Kompozit malzemelere giriş. Gazi Kitapevi, Ankara.

[22] Karamirad, M., Omid, M., Alimardani, R., Mousazadeh, H., \& Heidari, S. N. (2013). ANN based simulation and experimental verification of analytical four-and fiveparameters models of PV modules. Simulation Modelling Practice and Theory, 34, 86-98. https://doi.org/10.1016/j.simpat.2013.02.001

[23] Malik, H. \& Mishra, S. (2016). Artificial neural network and empirical mode decomposition based imbalance fault diagnosis of wind turbine using TurbSim, FAST and Simulink. IET Renewable Power Generation, 11(6), 889902. https://doi.org/10.1049/iet-rpg.2015.0382

[24] Rezk, H. \& Hasaneen, E. S. (2015). A new MATLAB/Simulink model of triple-junction solar cell and MPPT based on artificial neural networks for photovoltaic energy systems. Ain Shams Engineering Journal, 6(3), 873881. https://doi.org/10.1016/j.asej.2015.03.001

[25] Bhattacharya, A. \& Chakraborty, C. (2010). A shunt active power filter with enhanced performance using ANN-based predictive and adaptive controllers. IEEE transactions on industrial electronics, 58(2), 421-428. https://doi.org/10.1109/TIE.2010.2070770

[26] Sharon, H., Jayaprakash, R., Sundaresan, A., \& Karuppasamy, K. (2012). Biodiesel production and prediction of engine performance using SIMULINK model of trained neural network. Fuel, 99, 197-203. https://doi.org/10.1016/j.fuel.2012.04.019

[27] Sagawa M., Furimuro S., \& Matsuura Y. (1993). Magnetic Materials and Permanent Magnets. United States Patent, Patent. No: 5,183,516.

[28] Sagawa, M., Furimuro, S., \& Matsuura, Y. (1986). Magnetic Materials and Permanent Magnets. United States Patent, Patent. No:4, 597, 938.

[29] Beale, H. D., Demuth, H. B., \& Hagan, M. T. (1996). Neural network design. Pws, Boston.

[30] Fausett, L. (1994). Fundamentals of neural networks: architectures, algorithms, and applications. Prentice-Hall, Inc.

\section{Contact information:}

Mustafa KARHAN, PhD

(Corresponding author)

Cankiri Karatekin University, Electronics and Automation Department,

Tasmescit Campus, 18100 Cankiri, Turkey

E-mail: mustafakarhan@gmail.com

\section{Musa Faruk ÇAKIR, PhD}

Cankiri Karatekin University, Electronics and Automation Department,

Tasmescit Campus, 18100 Cankiri, Turkey

E-mail: mcakir@karatekin.edu.tr 